Jurnal Basicedu Volume 4 Nomor 4 Tahun 2020 Halaman 1370 - 1387

JURNAL BASICEDU

Research \& Learning in Elementary Education

https://jbasic.org/index.php/basicedu

\title{
The Readiness of Teaching English to Young Learners in Indonesia
}

Syifa Dwi Mutiah ${ }^{1}$, Minkhatun Nakhriyah ${ }^{2}$, Nida Husna HR $^{3}$, Didin Nuruddin Hidayat ${ }^{4}$, Farida Hamid $^{5}$

Department of English Education, Faculty of Educational Sciences, UIN Syarif Hidayatullah Jakarta 1,2,3,4,5

E-mail : syifadwimutiah@gmail.com ${ }^{1}$ minkhatun.riyah@gmail.com² nida.husna@uinjkt.ac.id ${ }^{3}$ didin.nuruddin@uinjkt.ac.id ${ }^{4}$ faridahamid@uinjkt.ac.id ${ }^{5}$

\begin{abstract}
Abstrak
Penelitian ini bertujuan menggali kesiapan guru, siswa dan sekolah dalam menyelenggarakan program bahasa Inggris untuk anak didik di Indonesia. Partisipan penelitian ini berasal dari tiga aspek sebagaimana tersebut di atas. Ada dua tingkat sekolah yang dilibatkan dalam penelitian ini, yakni tingkat SD dan Pra Sekolah yang terdiri dari 10 Guru Sekolah Dasar, Guru Pra Sekolah, Siswa SD dan Prasekolah, Sekolah Dasar dan Pra Sekolah di beberapa daerah di Indonesia. Pengumpulan data dilakukan melalui kuisioner dan difokuskan pada kesiapan mereka dalam berbahasa Inggris. Hasil penelitian ini menunjukkan bahwa dari kesiapan siswa dalam belajar Bahasa Inggris, motivasi mereka untuk belajar Bahasa Inggris sangat tinggi walaupun sering menemui kendala atau kesulitan. Sedangkan dari segi kesiapan fasilitas untuk mendukung proses belajar mengajar, fasilitas sekolah untuk mendukung pembelajaran Bahasa Inggris belum sepenuhnya lengkap. Di sisi lain, kesiapan guru tinggi meskipun mereka kurang percaya diri dalam menggunakan Bahasa Inggris di kelas dan ditemukan bahwa latar belakang pendidikan guru menjadi salah satu penyebabnya. Selain itu, pelatihan guru juga dibutuhkan untuk mengembangkan profesionalisme mereka. Namun, mereka juga menyatakan bahwa mereka belum mengikuti pelatihan tersebut. Oleh karena itu, kurangnya pelatihan pengembangan profesi menjadi salah satu faktor yang menurunkan kesiapan guru mengajar di tingkat SD dan TK.
\end{abstract}

Kata kunci: program bahasa inggris, kesiapan, guru, pembelajar muda

\section{Abstract}

This study attempted to investigate teachers, students, and schools' readiness in conducting English programs for young learners in Indonesia. Therefore, the participants of this study were from three aspects, as mentioned above. There were two levels of schools involved in this study. Those were elementary and pre-school levels consisted of 10 elementary school teachers, pre-school teachers, elementary and preschool students, elementary and pre-school schools in several areas of Indonesia. The data were collected through the questionnaire and focused on their readiness to conduct English at their level. This study showed that students' readiness to learn English was very high even though they often encounter obstacles or difficulties in the process of learning English in class. Meanwhile, facilities readiness to support the teaching-learning English process was not fully complete; the conditions and facilities were limited. On the other hand, the teacher readiness was high, although they lack confidence in using English in the classroom, and it was found that the teacher's educational background became one of the reasons. Additionally, teacher training was stated to be needed to develop their professionalism. However, they also stated that they had not joined that training yet. Therefore, less professional development training became a factor in decreasing the teacher readiness to teach at elementary and kindergarten levels.

Keyword: english program, readiness, teacher, young learners

Copyright (c) 2020 Syifa Dwi Mutiah, Minkhatun Nakhriyah, Nida Husna HR, Didin Nuruddin Hidayat, Farida Hamid

$\triangle$ Corresponding author

Address : Jl. Ir. H. Juanda No. 95 Ciputat

Email : didin.nuruddin@uinjkt.ac.id

Phone : 087731490180

DOI: https://doi.org/10.31004/basicedu.v4i4.541 
1371 The Readiness of Teaching English to Young Learners in Indonesia - Syifa Dwi Mutiah, Minkhatun Nakhriyah, Nida Husna HR, Didin Nuruddin Hidayat, Farida Hamid

DOI: https://doi.org/10.31004/basicedu.v4i4.541

\section{INTRODUCTION}

English is an international language widely used in many countries. Crystal (2003) stated that English could be seen as a symbol of globalization, diversification, and progress. Additionally, he also argued that it is used in many fields of society. Therefore, its role could be maintained as a world-wide audience achievement tool. The use of English may indicate the progress of globalization of a country. Likewise, Lie (2017) believed that English is in line with the political power, privilege, and social prestige since many other countries included English in their school curricula.

In Indonesia, English has been included in the curriculum as a subject. However, it is only included and introduced in the secondary school. Besides, Wahyudi (2018) presented that the formal curriculum allows English to be a formal subject in grades seven to twelve and university. Therefore, we can conclude that English becomes a formal subject for secondary to varsity students. However, globalization makes the parents and society demands improvement from time to time.

As a result, there is also a policy that discuss about English subject in the primary school. The Decree of the Ministry of Education and Culture No. 22/2006 about The Structure of National Curriculum described that English could be a local content subject in primary schools. This policy makes English become an option for primary school. Therefore, they can free to choose English to be in their curriculum or not. The undeniable globalization and parents demand finally to deliver English as a need for everyone. In line with Chang (2012) believed that introducing English at an early age had become a trend and a competition among the non-native countries. As a result, many elementary schools or even pre-schools hold an English program to offer society in preparing their children with English.

Lie (2017) presented that many English courses and English classes are flourishing in attracting children and their families starting from the middle class until the higher-class family. In a similar vein, Zein (2017) argued that there is a tendency for parents to enroll their children in a school that offers English. However, the competition of them only based on their affordance causes an imbalance standard offer to society because of their different capability to hold English programs on their institution. Supriyanti (2012) described that there are public and private schools of elementary. The number of them can consider the English program well. Vroom and Seaman (2014) found that teachers in private schools generally conduct sustainable professional development activities. It indicates that private schools are ready to hold an English program.

Yuwono and Harbon (2010) revealed that most elementary teachers do not have English background education and qualification. Most of them are in the only young learner qualification. Teaching English for young learners need many considerations. Similarly, Chang (2012) stated that the policymakers should always consider how the children begin to learn English based on their age. It can be said that age considers many things for schools to hold an English program. Reflecting on the above discussion, this study was aimed to investigate the teachers', students' and school 
1372 The Readiness of Teaching English to Young Learners in Indonesia - Syifa Dwi Mutiah, Minkhatun Nakhriyah, Nida Husna HR, Didin Nuruddin Hidayat, Farida Hamid

DOI: https://doi.org/10.31004/basicedu.v4i4.541

readiness in conducting English program in preschools and elementary schools.

The research question of this study will be mentioned as below:

1. How is the teachers' readiness to teach English for young learners?

2. How is the children readiness to learn English in their school?

3. How is the school's readiness to conduct an English program?

\section{Children and language development}

Teaching English to young learners needs to consider the learners' age either because of different ages they had makes different competence they perform too. Some of the development can be described as below. Fahriany (2018) believed that the critical age of learning language still becomes a speculation in society. She states that children's age in learning a second language begins from six until twelve years old. Piaget (1970) theory explained the children age and their developments as below. Four stages of children cognitive relation to language development too. Therefore, we can see that the children's learning language can be done in their golden age maximally. Additionally, Creese and Blackledge (2010) stated that many children become bilingual or multilingual in everyday reality. It means that many children learn language simultaneously.

Therefore, they can learn and produce English quickly. In this period, their brains are still flexible. Therefore, they can learn anything, including languages. Besides, children's attitudes to other languages and cultures are open, helping them learn the languages. Furthermore, children can learn many things at any stage, as long as the learning material is presented comprehensively. Above all, English teachers had better follow the cognitive development stage in developing competency standards and their school-based curriculum's basic competency.

Related to children development in their language, the teacher knows the children's characteristic, emotional aspect, and interest in their cognitive in teaching primarily teach the English language, which is different from adult learners because it will be an important role in how the young student certainly involved in the learning process, how they respond and how they achieve the objective lesson. Musthafa (2010) mentioned that children have a short attention span. It means that, unlike adult learners who can longer focus on their study, the children who have short pay attention only for about twenty minutes in their study. This means the teacher should have various teaching techniques for their activity in the class to avoid boredom on the student's part.

Another characteristic of young learners is the difficulty to distinguish concrete and abstract, and it means young learners 5-7 years old still difficult to distinguish between concrete and abstract things. When the teacher gives English subject to young learners, it should begin with tangible things. Moreover, in teaching-learning process should involve a cognitive aspect. Many more objects around those objects can be utilized as a concrete object, related to Pinter (2011), young learners can solve problems which are applied to concrete examples and objects in real life. 
1373 The Readiness of Teaching English to Young Learners in Indonesia - Syifa Dwi Mutiah, Minkhatun Nakhriyah, Nida Husna HR, Didin Nuruddin Hidayat, Farida Hamid

DOI: https://doi.org/10.31004/basicedu.v4i4.541

Furthermore, young learners, in general, are very active and imaginative. Kuchah (2013) stated that they like using participatory activities, such as drawing, storytelling, listening to music. It means that they like learning through story games and songs, so they are more motivated to learn English even indirectly because playing is a part of children's daily lives and can be utilized to carry out the learning process.

Young children (5-7 years old) have an egocentric attitude that focused on themselves and unable to receive other perspectives than their own, which there is a tendency like to connect what they learn or do with themselves. Furthermore, they like the material of the subject related to their daily life and around them. New young learners will be proud when their teacher teaches them about their own, and it is long-term in their memory to remember the subject.

When the young children grow to 10 years old, they are processing change to reciprocity, which their attention does not in themselves. However, they try to give others (Donaldson, 1978 \& Hughes, 1986, cited in Uysal \& Yavuz (2015). They need to involve in hands-on experiences for effective learning.

\section{Teaching English to Young Learners}

Related to language learning, the most important thing to understand is that language learning becomes an acquisition process to achieve communication skills. One of the important factors in teaching English to young learners is the teachers' profile because they should introduce a foreign language to young learners, which is a second language for them.
Also, the teachers can facilitate children learning English as a foreign language, as argued by Turek (2013). A good English teacher must guide the young learners because it can improve their achievements.

Furthermore, the children who have lived abroad for a long time with their daily communication in English will have superior English skills compared to students who are entirely new to English. Therefore, there are three levels, namely beginner, intermediate, and advance, so that the teacher understands their level in teaching the English language; the teacher must be sensitive to the children's ability level (Supriyanti, 2014).

On the other hand, considerations for young learners, learning resources must be appropriate for children's aptitude. Materials and methods of young learners are appropriate in teaching English based on their age, such as using the TPR method, which is one of the language methods that include command, speech, and action that are improving their memory. According to Putri et al. (2020), remembering is verbal with motoric activity.

Also, there must be a straightforward distinction technique likes providing songs, stories, and games. Games and songs can be used to teach English, such as vocabulary, pronunciation, and fluency also can introduce the public and culture of the user English as the first language (Supriyanti, 2012).

\section{Advantages and Disadvantages of TEYL Advantages}

Language acquisition is a process that takes place in a child's brain when he gets his first 
1374 The Readiness of Teaching English to Young Learners in Indonesia - Syifa Dwi Mutiah, Minkhatun Nakhriyah, Nida Husna HR, Didin Nuruddin Hidayat, Farida Hamid

DOI: https://doi.org/10.31004/basicedu.v4i4.541

language or mother tongue. According to Chomsky, when the children gain language skills, the innateness hypothesis is that humans are born equipped with a tool to speak easily and quickly. Hence, an advantage of learning English from an early age is communicating with a foreign language by the right cognitive side. It is time golden age to acquire a second language. Furthermore, introducing English to children is necessary to pay attention to the theory of language development.

Handayani (2016) presented some theories of language development: a). Nativism theory which explains that language skills are influenced by maturity as a child grows. Furthermore, nativism argues that while acquiring the first language, the child gradually unlocks his verbal abilities that have been genetically programmed. b). Behaviorist theory, which is young learners learn language by imitating what they hear and look. Children learn languages by imitating or imitating a model. c). Cognitive theory mention that the child's early language development is closely related to various children's activities, objects, and activities that he experiences, such as hearing, feeling, seeing.

According to Supriyanti (2012), some reasons why children need to keep learning English are presented:

\section{a. Other countries are ready to introduce} English from Elementary School.

British Council and Aston University (2011), as cited in Supriyanti (2012), reported that there are 144 countries from all the continents that use English subjects in their elementary school. Therefore, the children in
Indonesia need to learn it too. That, they will have enough prior knowledge and better proficiency later.

\section{b. High demand of society}

The demand of the society to the children is getting higher. Supriyanti (2012) claimed that the society in Indonesia thinks that English is a subject in school and a necessity in their life. In conclusion, society needs English in their daily life or development life. Hence, they must master it earlier.

\section{c. More opportunities in early age}

The Critical Age Theory mentions that cognitive development is believed as the golden age of children in English learning. Young learners may have more opportunities to hear and speak the language in an environment where they feel secure and do not feel the pressure of communicating grammatically correct. In contrast, older learners are more often in situations where they must use a more complex language. Therefore, the children not only can practice English daily for a long time; they also can do it freely and optimally. However, teaching English to young learners has a disadvantage side. According to Grigg (2015), when the young learners are taught language in their school, worry becomes semi-lingual, it means the young learners are taught English but cannot master each language in full. As a result, the language ability becomes overwhelming and mixed.

Furthermore, when the young learner starts to study in the school, certainly, they are introduced to a new language, it is become 
1375 The Readiness of Teaching English to Young Learners in Indonesia - Syifa Dwi Mutiah, Minkhatun Nakhriyah, Nida Husna HR, Didin Nuruddin Hidayat, Farida Hamid

DOI: https://doi.org/10.31004/basicedu.v4i4.541

exposure of the mother tongue gradually decreases. This can trigger difficulties in academics and social abilities of children in the future. Therefore, according to Grigg (2015), a child should have mastered his or her mother tongue before being introduced to additional languages.

Teaching English to Young Learner in Indonesia

This part attempts to present the teaching English to young learners, especially in Indonesia. Talking about language teaching in Indonesia will automatically bring us to know the position of English subject in Indonesia. English lesson has been implemented in some schools since 1992, and its position is a local content subject (Zein, 2017). In line with it, the Ministry of Education and Culture Number 0487/4/1992, Chapter VIII, states that schools can some basic subjects to their school's curriculum as long as they are supporting the national education goals.

Then, the policy has been emphasized by the Decree of the Ministry of Education and Culture Number 060/U/1993 dated February 25, 1993. It is about the addition of English programs as local content in elementary school, which can be begun in the fourth grade. Additionally, Hawanti (2014) stated that local content subjects in elementary schools have 35 minutes per week from the fourth until the sixth of elementary school.

Therefore, in Indonesia, the English subject in primary schools or young learner areas is considered a local content subject that is not giving negativity to Indonesia's educational goal.
This policy will affect the development of the English teaching language. Musthafa (2010) argued that English as a foreign language and as a local content in elementary school requires extra hard work for teachers. Teachers need to struggle with the limited time since children only have a short limited span of attention. The teachers should maintain the interests of young learners in engaging the English subject. Additionally, its language's unclear social function makes the motivation of language learners low either.

However, Cui (2016) asserted that some significant factors that influence learners' learning and teaching process are external and internal, such as physical, family, and society. Whereas, the use of local and foreign language does not influence the learners' learning process.

The development of English language teaching could be seen as Indonesia's effort in answering and following the global development effect through the English language. Likewise, Cameron (2009) described some aspects that make English medium instruction in everyone's daily lives.

First, the statistical fact that non-natives are now becoming the majority of English users. Second, the awareness of English that is used in a multilingual context. Therefore, it draws a successful communication. Third, the ability to negotiate meaning is more acceptable than the grammatical accuracy and the native sounding. It implies that despite all grammar and pronunciation rules, English is now used as a daily life communication for mostly non-native people. Additionally, Mappiasse and Sihes (2014) conveyed that in Indonesia, English is a teaching 
1376 The Readiness of Teaching English to Young Learners in Indonesia - Syifa Dwi Mutiah, Minkhatun Nakhriyah, Nida Husna HR, Didin Nuruddin Hidayat, Farida Hamid

DOI: https://doi.org/10.31004/basicedu.v4i4.541

language in higher education and a standard medium of global communication.

Zein (2012) said that some parents are now sending their children to a school that adds English instruction. However, the Ministry of Education and Culture's local office does not oblige them to do so because of a prestige overview. The availability of qualified English teachers does not support parents' demand for English in primary school. As the evidence, Lie (2017) argued that English had been taught as a foreign language in the formal curriculum at 7 th grade through 12th, followed by the university level.

However, many private schools add English to their kindergarten level and many attractive English courses that exist, although some of the tutors seem inadequate to make instruction with English. In line with Article 33 of the National Education System Law No. 20/2003 permit the use of local languages and foreign language in the early years of instruction in schools (Lie, 2017). Thus, young learners can learn English earlier despite the compulsory of the national education system. Because of globalization, it builds the overview that English considers the demands of people since it is widely used in society.

Therefore, Zein (2012) suggested that future Indonesian challenges in considering the development curriculum should be based on the society transformation both locally, nationally, and globally because of the influence and impact of echo-sciences and the quality, investment, and transformation of education.

The adoption of the English language by Indonesia creates many changes in the field of educational policies. As a result, the aspect of English, such as methodologies, curriculum, and evaluation of language teaching, is changing either (Mappiasse \& Sihes, 2014). The Indonesian policy about English subject in elementary school has been transformed since 1994. Sulistiyo et al. (2019) classify the transformation of English in elementary school as below.

Table 1. Transformation of English Curriculum

\begin{tabular}{|l|l|l|}
\hline Year & $\begin{array}{l}\text { English } \\
\text { position }\end{array}$ & Curriculum \\
\hline 1993 & Local & Meaning \\
& $\begin{array}{l}\text { content } \\
\text { subject }\end{array}$ & curriculum \\
\hline 1994 & Local & Meaning \\
& content & based \\
subject & curriculum \\
\hline 2013 & Optional & 2013 \\
& lesson & curriculum \\
\hline
\end{tabular}

As we can see from the table above, English policy in elementary school is changed based on the policymaker consideration. Along with this, Zein (2017) also explained that positioning English as a local content subject in primary school is a linguistic consideration and the economic, social, and political consideration. All in all, this becomes a phenomenon of the high demand for English but the low capacity we still have. The capacity comes from many aspects, such as class size, teacher professionalism, and elementary school infrastructure.

Sulistiyo et al. (2019) found that the government did not provide enough learning resources such as English textbooks and other supported English learning media. Consequently, 
1377 The Readiness of Teaching English to Young Learners in Indonesia - Syifa Dwi Mutiah, Minkhatun Nakhriyah, Nida Husna HR, Didin Nuruddin Hidayat, Farida Hamid

DOI: https://doi.org/10.31004/basicedu.v4i4.541

the teachers should cope with their creativity in developing the learning material for young learners. However, Yuwono and Harbon (2010) research revealed that the majority of elementary teachers do not have English background education and qualification. Most of them are in the only young learner qualification. Additionally, Zein (2017) showed that in Indonesia, the English Department only provides the English education students the preparation for teaching in higher and secondary schools for their future teaching. In short, the English education program in university and the policymaker should relate and cooperate with the ideas regarding English in elementary school. Hence, the young learners can still have English conscientiously and adequately.

\section{METHOD}

\section{Participants}

The participants of this study were the 10 teachers of elementary and pre-schools, consisting of five male and five female teachers. They are classified based on their year of teaching. Furthermore, they came from government and private schools. Three teachers were from a government school, and the rest were from private schools.

Besides, there were also ten teachers of preschool. All of the pre-school teachers were female which could be classified according to their year of teaching experiences. Additionally, there were ten young learners, divided into two levels: elementary and pre-school levels. The elementary school students consisted of five males and five females. They came from the fourth class of elementary schools, in line with the pre-school students classified based on their age, five years old. Specifically, five males and females were selected in this study. The participants in this study is described below.

Table 2. Participants of the Study

\begin{tabular}{|c|c|c|c|c|}
\hline PARTICIPANTS & AMOUNT & $\begin{array}{l}\text { WORKING } \\
\text { EXPERIENCE }\end{array}$ & INSTITUTION & LOCATION \\
\hline Elementary Teachers & $\begin{array}{l}5 \text { male teachers } \\
5 \text { female } \\
\text { teachers }\end{array}$ & $\begin{array}{l}3-6 \text { years } \\
\text { experiences } \\
3-6 \text { years } \\
\text { experiences }\end{array}$ & $\begin{array}{l}\text { SDN \& SDS } \\
\text { SDN \& SDS }\end{array}$ & \begin{tabular}{|l|} 
2 Jkt, 1 Bali, 1 \\
Kalimantan, 1 \\
Bandung \\
2Jkt, 1 Kalimantan, 1 \\
Bandung, 1 Lampung \\
\end{tabular} \\
\hline Pre-school Teachers & $\begin{array}{l}10 \text { female } \\
\text { teachers }\end{array}$ & $\begin{array}{l}\text { 3-6 years } \\
\text { experiences }\end{array}$ & Private School & \begin{tabular}{|l|} 
2Jkt, 2 Bandung, 2 \\
Lampung, 1 Bali, 2 \\
Kalimantan, 1 \\
Sulawesi. \\
\end{tabular} \\
\hline Students & $\begin{array}{l}10 \text { elementary } \\
\text { school students } \\
\text { (5 boys, } 5 \text { girls) } \\
10 \text { pre-school } \\
\text { students } \\
\text { ( } 5 \text { boys, } 5 \text { girls) }\end{array}$ & $\begin{array}{l}4 \text { grade } \\
\text { elementary } \\
\text { school students } \\
5^{\text {th }} \text { years old } \\
\text { students }\end{array}$ & $\begin{array}{l}\text { SDN \& SDS } \\
\text { Private pre- } \\
\text { schools }\end{array}$ & $\begin{array}{l}5 \text { boys; } 2 \text { Jkt, } 3 \\
\text { Bandung. } \\
5 \text { girls; 2 Jkt, } 3 \\
\text { Bandung. } \\
\\
5 \text { boys; } 3 \text { Lampung, 1 } \\
\text { Jakarta, 1 Bali } \\
5 \text { girls; 2 Jakarta, 1 } \\
\text { Bandung, 1 Bali, 1 } \\
\text { Lampung } \\
\end{array}$ \\
\hline
\end{tabular}

\section{Setting}

The setting of this research was divided into two settings - the elementary schools and preschools in Indonesia. The specification of the place was Jakarta, Bandung, Bali, Lampung, Sulawesi, and Kalimantan.

\section{Data Collection and Analysis}

Data were collected through the survey method by questionnaire. This study employed a qualitative methodology, particularly a case study, to investigate teachers, students, and the school's readiness in conducting English as a subject for young learners. The qualitative methodology was chosen because it was appropriate for the study's goals investigating and analyzing the readiness of teachers, students, and schools in conducting the English program in depth. Besides, to analyze the data by using percentage and explanation by presenting tables of survey results. 
1378 The Readiness of Teaching English to Young Learners in Indonesia - Syifa Dwi Mutiah, Minkhatun Nakhriyah, Nida Husna HR, Didin Nuruddin Hidayat, Farida Hamid

DOI: https://doi.org/10.31004/basicedu.v4i4.541

\section{RESULT AND DISCUSSION}

\section{Result}

\section{Teacher's readiness}

There were two significant parts of readiness coming from the teacher. Firstly, the teachers' competency readiness, which mainly discusses about pedagogical knowledge of the teachers. Next, the teachers' emotional attitudinal readiness will be based on teachers' attitudes towards being English teachers for kindergarten or elementary schools.

The aspect of teachers' competencies was divided into three parts: first, the teachers' language competence that generally describes the teachers' language proficiency. Based on this study's result, $45.5 \%$ of teachers' answer that they are often joining the English proficiency test. Furthermore, the teachers' language ability, especially in listening to English from their students, was $78.5 \%$. Next, the use of English during their subject was generally lower in their percentage. There are only $15.6 \%$ of teachers that use it during the class.

On the other hand, the lowest percentage of using English was 70.2\%. Using English in the classroom will automatically make them become role models of English speaking or pronunciation. Therefore, the number should be high for them who frequently use English during the teaching activity. Furthermore, $78.8 \%$ teachers answered that they became a role model in the classroom. Young learners tend to imitate adults.

Next, the pedagogy competence that showed the teachers ability to engage the classroom management. Practically, kindergarten and elementary teachers have applied their pedagogical competencies in the classroom. Furthermore, in the seating arrangement, $45.4 \%$ of them always organize their students' seating arrangements regularly. However, the assessment, media consideration, and lesson plan preparation were in high percentage for them. It is between $87.9 \%$. This concludes that they have enough pedagogical competence in teaching English.

Furthermore, the teachers' knowledge about their students/children reported a high willingness to understand their characteristics. However, the percentage showed that joining teacher training in the lower percentage is about $15.2 \%$. The percentage of making lesson plans based on the students' characteristics was in low number it is only $15,2 \%$ of them who always make it.

The second part was coming from the intrinsic aspect of teacher readiness. That is emotive attitudinal readiness (Saputri, 2016). There were responsibility, enthusiasm, willingness to adapt, independence, and reward to intrinsic value as the aspect of teachers' attitudinal readiness. The result showed that $92.8 \%$ of teachers agreed that they teach based on the curriculum provided. Furthermore, the data showed that half of them have $50 \%$ confidence in English and still want to develop it. Their enthusiasm described that they are highly willing to create an English environment for their students and spirit to teach English. Their willingness to adapt will 
1379 The Readiness of Teaching English to Young Learners in Indonesia - Syifa Dwi Mutiah, Minkhatun Nakhriyah, Nida Husna HR, Didin Nuruddin Hidayat, Farida Hamid

DOI: https://doi.org/10.31004/basicedu.v4i4.541

also influence their readiness. The data showed that they have a significant effort to adapt and understand the young learners' area. $92.9 \%$ of them tend to use children communication strategy. Further, $85.7 \%$ of them were trying to join children world development to make them more accessible in absorbing English subjects.

Their comfort and independent feeling were also becoming their readiness aspect. They have high expectation ( $84.6 \%$ teachers) that English become easier and understandable subject. The reward and intrinsic value of them were in a high percentage. They tend to reach their learning objective maximally in $78.6 \%$. Besides, they feel happy to be an English teacher at elementary school and kindergarten level. It means, emotionally, they feel happy to be an English teacher at the elementary or kindergarten level.

Meanwhile, the result of readiness teaching-learning English to young learners in Indonesia from the questionnaire survey as shown:

Table 3. The Readiness of Teaching

\begin{tabular}{|c|c|l|l}
\hline No & \multicolumn{2}{|c|}{ Emerging themes } & $(\%)$ \\
\hline 1 & Level of School & SD & 77 \\
\cline { 3 - 4 } & & TK & 23 \\
\hline 2 & \multirow{2}{*}{$\begin{array}{l}\text { Status of } \\
\text { School }\end{array}$} & Privat & 50 \\
\cline { 2 - 4 } & Government & 50 \\
\hline 3 & City of School & Jakarta & 80 \\
\cline { 3 - 4 } & & Bandung & 7 \\
\cline { 3 - 4 } & & Kalimantan & 2 \\
\cline { 3 - 4 } & & Lampung & 5 \\
\cline { 3 - 4 } & & Bali & 3 \\
\cline { 3 - 4 } & & Sulawesi & 5 \\
\hline 4 & \multirow{4}{*}{ Gender } & Female & 39 \\
\cline { 3 - 4 } & & Male & 61 \\
\hline
\end{tabular}

The table above shows that both elementary and kindergarten levels implemented English subjects at the elementary level as one of the local content in their school. It means teaching English in young children in great demand among private and government schools. Besides, this study attempts to survey teaching English to young learners in Indonesia in six cities. As mentioned in number 3 survey provides the highest percentage of city the English subject was Jakarta city, including elementary and kindergarten. The second was Bandung. The lowest percentage from the resulting survey implementing the English subject was in Kalimantan and Bali, which still low taught English subject to young learners in Elementary also kindergarten. On the other hand, from the survey result, females are highest than males who study English subjects in their school.

\section{Student's readiness}

In this study, the survey results about the students' readiness are divided into three, as mentioned in the resulting survey above, firstly from their motivation, then their characteristics, and the last one from using the media side.

\section{Student's motivation}

Most students from various cities like to learn English subjects, which was an interesting subject for them. However, in contradictory, they feel the English subject was a difficult one. Furthermore, in numbers 4 and 5 , they always pay attention and do some assignments when the teacher is given and explained even though they often found some obstacles in the English subject's learning 
1380 The Readiness of Teaching English to Young Learners in Indonesia - Syifa Dwi Mutiah, Minkhatun Nakhriyah, Nida Husna HR, Didin Nuruddin Hidayat, Farida Hamid

DOI: https://doi.org/10.31004/basicedu.v4i4.541

process. It means their motivation to learn English is very high even though they often encounter obstacles or difficulties in learning English in class. They always try to ask questions when the teacher asks questions about the English language they are studying. They also help each other when their friend finds difficulties in learning English, as shown in survey numbers 7 and 8 .

Characters of young children in study English

There were three components of characteristics of young children in learning English subjects: cognitive development, academic competence, and socio-emotional maturity. It can be seen from the table in cognitive development most of the students already have the basic abilities to take English lessons such as writing, mentioning vocabulary, reading English sentences. However, they cannot write some sentences or vocabularies in English yet by dictation or without looking at to book. Besides, a little by little, the students understood what the teacher says when delivering an explanation using English language as resulted survey mention above.

Meanwhile, every student has different competence in academics. Therefore, readiness to study English subjects should have certain academic competence. As from the table, the survey shows that the students could practice some vocabularies which have been gotten from the learning process and practicing some sentence use the English language to their friends or teachers. Nevertheless, they are able not to pronounce some sentences and vocabulary yet correctly. On the other hand, becoming a child's character was an egocentric attitude that focused on themselves and unable to receive other perspectives than their own. There is a tendency like to connected what they learn or do with themselves as a data survey show that the students sometimes did the assignments without helping their friends. So, it can be concluded that the student's cognitive development in learning English from this study good enough in their abilities.

\section{Compatible media use in learning English}

Feel of boredom quickly has become one of the children's characteristics, especially in learning activities. Therefore, for the teacher who teaches young children exactly in English subjects, the teacher should have a diverse teaching strategy supported by appropriate teaching media tools. According to the survey result, while teaching English in the classroom, their teachers always fun when delivering English materials. It means the teacher can provide varied teaching methods, which become enhance student's feel fun and happy. Further, the teachers invite the students to play some games related to the subject and always use appropriate teaching to enhance English teaching-learning activities in the classroom.

\section{Readiness facilities (Infrastructure and management support}

Ideally, implementing teaching English to young learners should well prepared from infrastructure and management support in their schools. Those included facilities, well English 
1381 The Readiness of Teaching English to Young Learners in Indonesia - Syifa Dwi Mutiah, Minkhatun Nakhriyah, Nida Husna HR, Didin Nuruddin Hidayat, Farida Hamid

DOI: https://doi.org/10.31004/basicedu.v4i4.541

programmed. From the data survey, readiness facilities for teaching English to young learners in Indonesia are incomplete yet such as few to have some English comics, magazines, native speakers, and annual outing programs to enhance English language students' skills. Meanwhile, most of their schools provide or have a complete English dictionary, story books, and preparing technological devices such as computers and laptops to learn English. Thus, it can be concluded from the data survey that school facilities to support learning English are not yet fully complete. Even though the conditions and facilities are limited, the principal and their English teachers always pays attention to try practicing students' abilities in the English language and continues to be creative, such as through decorating the classroom by giving names in English.

\section{Discussion}

The aspect of language competency of teachers was relatively high, especially in teachers' ability to listen to children' English speaking. Furthermore, thy also make their teacher a role model of English speakers in the classroom. However, the teacher did not use English during their teaching activity; it is about $70 \%$. This became a gap between students' impressions about their teacher and the reality that they did not use English during the learning process.

Zein (2017) found that English teachers at the elementary school level did not use English in their teaching activities for several reasons. Firstly, their lack of confidence. This makes the teacher misguided the right pronunciations of English to their students. Second, the demand from the student to use their first language. Third, the teacher tends to focus only on those who do not understand the meaning of teachers' English speaking. Therefore, it makes them who have enough Basic English did not develop maximally. Besides, Zein (2016) also found that the teacher who is not confident with their English tends to have difficulty using language for instruction. Meanwhile, Musthafa (2010) stated that children learn and acquire knowledge from their direct experience. Then, they pursued it through their sense and experience. It can be said that young learners need to experience English as like as their real environment created by the teachers.

Contrary to reality, the data showed that the teachers did not use English regularly in the classroom while they believe that they become models for many students. This becomes a gap between students' opinions of their teachers as their role model and the teachers' lack of English usage in the classroom. Young learners need teachers to be ideal models to speak English (Sayer, P., \& Ban, 2014; Yussof \& Sun, 2020). However, the teachers tend to do code-switching in the classroom. Thus, it decreased the number of students' vocabulary. Besides, this research showed the lowest number of teachers' English usage in the classrooms while it was highest in the students' opinion about them as the role model. Young learners need much exposure to use English by experiencing the English environment built by the teachers. This is supported by Sunyakul and Teo (2020). They reported that English for young learner teachers in a Boot 
1382 The Readiness of Teaching English to Young Learners in Indonesia - Syifa Dwi Mutiah, Minkhatun Nakhriyah, Nida Husna HR, Didin Nuruddin Hidayat, Farida Hamid

DOI: https://doi.org/10.31004/basicedu.v4i4.541

Camp Thailand is rarely applied Storytelling and role play because of the limit of knowledge and techniques that affected their communicative performance in the classroom.

Pogosian (2008) believed that young learner teachers should have foreign language communicative competence, linguistic competence, linguistic-cultural competence, and pedagogical competence. Some factors may cause this gap. First, the teacher themselves, their background of English but not special for young learners. Furthermore, 20\% teachers are coming from general English background in this study. Moreover, $10 \%$ of them did not have a bachelor degree yet. This makes the performance and pedagogical competence of them vary. Zein (2017) described that the generalist teacher tends to use the traditional approach while the young learner learning development and characteristics need to be considered significantly. This becomes a big struggle for them who teach English at elementary school. However, they graduate from only English education departments or do not have any bachelor degree yet (some found in kindergarten). Besides, both Kindergarten and Elementary school English has still become a burden for some generalist teachers.

Sulistiyo et al. (2019) stated that English as a local content for elementary school level makes English has no mandated curriculum guidelines. This makes English teacher to be more creative in designing, applying, and assessing their subject. However, the generalist and no title teacher might have not enough knowledge to do it. However, teacher training is still considered to help enrich the young learner teacher competence. Zein
(2016) found that professional development or training for young learner teachers in Indonesia is limited because the training provided is a mismatch with the needs of young learners. This relates to the data obtained in this research where only a few teachers join teacher training provided by their school or government. This makes the quality of them not developed well or even stuck. Above all, the young learner teachers' pedagogical competence, linguistic, and knowledge are based on the status of English, the government provision of professional development training.

The government policy about English subjects at lower-level education should be clear because Indonesia does not have English for young learners major at the varsity level, creating English for young learner teacher specialists. Thus, there must be a match between the government policy and their English provision for young learner training and young learner program for teaching faculty. Yuwono and Harbon (2010) research revealed that most elementary teachers do not have English background education and qualification. Most of them are in the only young learner qualification. Additionally, Zein (2017) showed that in Indonesia, the English department only provides the English education students the preparation for teaching in higher and secondary schools for their future teaching.

The following session will elaborate on the result of teachers' emotive attitudinal readiness. This describes the teacher perception of their willingness, enthusiasm, and feeling about their English teacher position at kindergarten and elementary school level. Most of them agree to 
1383 The Readiness of Teaching English to Young Learners in Indonesia - Syifa Dwi Mutiah, Minkhatun Nakhriyah, Nida Husna HR, Didin Nuruddin Hidayat, Farida Hamid

DOI: https://doi.org/10.31004/basicedu.v4i4.541

teach English based on the curriculum provided. However, the data found that some of them have no title and come from general English as curriculum regulated. They also showed that only half of them feel confident about their English ability and willingness to develop it. Gil and Crichton (2018) conveyed their study where the young learner teachers have high enthusiasm to teach English but still not sure to practice it because of the grammar and pronunciation challenge. Likewise, Fransischa and Syafei (2016) stated that the children failed to acquire new pronunciation if they got it from the inappropriate sources. Thus, teachers might have a high demand to be the ideal model of English speaking.

The teacher willing to adapt are in high percentages. They believed that they used simple instruction to their students and tried to follow their students' world to deliver English. Furthermore, they want to make their subject understandable. They, they reach the learning goal maximally. Sulistiyo et al. (2019) declared that the teacher's role is important to be the main source and facilitator of foreign language skills in the classroom. Therefore, the main objective of learning is based on the teachers' effort.

However, teachers would have big challenges in reaching the goal because of the local content subject position of English that they must prepare, modify, and arrange their learning material independently. Hawanti (2014) found that the teachers' basic knowledge of developing an English program was not adequate to deliver English as a local content subject. They often ended up in the textbook, which mainly deals with the traditional approach. Therefore, this research showed high emotive attitudinal readiness to teach at young learners at kindergarten and elementary school. However, they would have great challenges because of the lack of background knowledge and professional development activity that only a few join.

Even though English was considered a difficult subject for young learners, it is still one of the interesting subjects to be learned by them. Thus, conducting this program was inevitable and required good preparations. Some of those preparations are doable lesson plans, affordable supporting facilities, and having student readiness. Handayani (2016) mentioned that introducing the English language to young learners was easier to achieve naturally or informally. Therefore, it requires adequate planning in teaching programs, including preparing the teachers, choosing the materials to be learned, providing sufficient facilities, including the learning settings. Those preparations should consider young learners' characteristics because they will play a major role in achieving language learning objectives.

English was only a local content in elementary schools with little function in social relations or communication, especially in Indonesia (Musthafa, 2010). However, another study showed that young learners' motivation factor in learning this language was good enough. They give their attention and keep a sense of enthusiasm for learning English.

Furthermore, Cognitive Theory regarding language mastery mentioned that language ability does not separate the natural feature but in one of the abilities coming from cognitive maturity. It is structured by common sense that language 
1384 The Readiness of Teaching English to Young Learners in Indonesia - Syifa Dwi Mutiah, Minkhatun Nakhriyah, Nida Husna HR, Didin Nuruddin Hidayat, Farida Hamid

DOI: https://doi.org/10.31004/basicedu.v4i4.541

development must be grounded and fundamental in cognition (Piaget, 1970). One line from the results survey about young learners' character, which includes cognitive development in language by students' cognitive abilities that they were able to read, group some vocabularies, write in English form (Chaer, 2009). Related to academic competence, which showed in the result, the students tried to practice English although they have not pronounced them correctly yet. This result was in line with Ni'matuzahroh et al. (2019) study, which revealed that students should have social competence and communicate in English to be practiced. However, those aspects still were not sufficiently prepared in their learning experience. Therefore, every student should work hard to practice and learn those language skills in their own circle first, including practicing speaking skills with their friends. Having some discussion activities by a group in the learning process, although English is still limited and incompletely correct in pronunciation side, will still be helpful.

Meanwhile, the dominant characteristics of young learners were egocentric (Stakanova \& Tolstikhina, 2014). This case needs to be considered in teaching English to young learners not to become egocentric characters that were not favorable among societies. Many teaching approaches can be applied to help the young learners, so they become more open-minded persons. Those including some activities such as invited them to sing together, role-playing, discussing pictures, problem-solving, and using other visual props or aids that make them more active to work together. Those activities, hopefully, will reduce their sense of egocentricity in the English learning process.

Related to students' readiness to learn English from academic competence, social maturity, and their characteristic side, it must be supported by the school's readiness, which is an essential requirement to increase students' competence in English. As defined by Magdalena (2014), school readiness means certain conditions that the students can practice their skills and enhance their school activities supported by infrastructure and management support. However, the survey results have shown that the readiness facilities for teaching English to young learners in Indonesia were still incomplete yet. Meanwhile, it was unavoidable that the English subject has been demanded to be learned by young learners. Therefore, several preparations should be well accomplished to conduct the program, such as the annual English program, supporting technologies, including supporting facilities such as libraries consisting of dictionaries, books, or comics and storybooks in the English language. Curtain and Dahlberg (2000) reminded that if teaching English does not involve the target language, it will be difficult to be conveyed by the students. In the end, it will affect the process of acquiring the language itself. Therefore, it is essential that the prepared facilities can support the process.

\section{CONCLUSION}

Teaching English for young learners in Indonesia is a part of introducing English to them. It should also consider many things before conducting English at the young learner level. The consideration may come from the aspect that 
1385 The Readiness of Teaching English to Young Learners in Indonesia - Syifa Dwi Mutiah, Minkhatun Nakhriyah, Nida Husna HR, Didin Nuruddin Hidayat, Farida Hamid

DOI: https://doi.org/10.31004/basicedu.v4i4.541

supports the learning and teaching process, whether the supporting aspects have ready or not. The readiness of teachers can affect the students' readiness. In comparison, the readiness of school will affect the teacher readiness. The readiness of them is connected. Therefore, the factor that influences the readiness of those aspects should be prioritized by the English program holder. The teacher lack of confidence in using English affects the students' pronunciation correctness since young learners tend to make a teacher role model of English speaking. Moreover, the facility of English learning teaching will automatically support the learning process effectively and efficiently. Meanwhile, it attracts the students' motivation to learn English more.

Several limitations of this study can be a suggestion for future research. Further research that will discuss this topic needs to prepare a more profound understanding regarding the readiness term. Besides, the next researcher's deeper instrument about readiness could be done to get more valid research results. Further research about what makes the teacher's lack of confidence and how to increase teachers' confidence are expected.

\section{REFERENCES}

Cameron, L. (2009). Teaching languages to young learners. Cambridge University Press.

Chaer, A. (2009). Psikolinguistik: Kajian teoretik. Rineka Cipta.

Chang, P. (2012). Using a stance corpus to learn about effective authorial stancetaking: A text linguistic approach. ReCALL Journal, 24, 209-236.

Creese, A., \& Blackledge, A. (2010).
Translanguaging in the bilingual classroom: A pedagogy for learning and teaching? Modern Language Journal, 94(1), 103-115.

Crystal, D. (2003). English as a global language. Cambridge University Press.

Cui, Q. (2016). A study of factors influencing students' intercultural competence. Journal of Language Teaching and Research, 7(3), 433-439.

Curtain, H., \& Dahlberg, C. (2000). Planning for success: Common pitfalls in the planning of early foreign language program. ERIC Digest.

Fahriany. (2018). Second Language Acquisition. Prenadamedia Group.

Fransischa, A., \& Syafei, A. F. (2016). Using song to teach English to young learners. Journal of English Language Teaching, 5(1), 252258.

Gil, F. D., \& Crichton, H. (2018). Mother tongue plus two languages: Are Scottish primary teachers confident to deliver? The Language Learning Journal, 48(4), 454-468.

Grigg, R. (2015). Becoming an outstanding primary school teacher. Routledge.

Handayani, S. (2016). Urgensi pengenalan Bahasa inggris pada anak usia dini di pandang dari prespektif Psikolinguistik. Jurnal Widya Wacana, 11(2), 173-184.

Hawanti, S. (2014). Implementing Indonesia's English language teaching policy in primary schools: The role of teachers' knowledge and beliefs. International Journal of Pedagogies and Learning, 9(2), 162-170.

Kuchah, H. (2013). Context-Appropriate ELT pedagogy: An investigation in Cameroonian primary schools. University of Warwick.

Lie, A. (2017). English and identity in multicultural contexts: Issues, challenges, and opportunities. TEFLIN Journal, 28(1), 71-92.

Magdalena, S. M. (2014). The effects of parental 
1386 The Readiness of Teaching English to Young Learners in Indonesia - Syifa Dwi Mutiah, Minkhatun Nakhriyah, Nida Husna HR, Didin Nuruddin Hidayat, Farida Hamid

DOI: https://doi.org/10.31004/basicedu.v4i4.541

influences and school readiness of the child. Procedia - Social and Behavioral Sciences, 733-737.

Mappiasse, S. S., \& Sihes, A. (2014). Evaluation of English as a foreign language and its curriculum in Indonesia: A review. English Language Teaching, 7(10), 113-122.

Musthafa, B. (2010). Teaching English to Young learners in Indonesia: Essential Requirements. Educationist Journal, 4(2), 120-125.

Ni'matuzahroh, Suen, M. W., \& Sholihah, A. M. (2019). High validity and reliability of school readiness questionnaire measuring instrument for kindergarten children in Indonesia sample. Journal of Psychological and Educational Research, 27(2), 126-153.

Piaget, J. (1970). The science of education and the psychology of the child. Oxford University Press.

Pinter, A. (2011). Children learning second languages. Oxford University Press.

Pogosian, V. (2008). The Russian system of training teachers of foreign languages for young learners: History and new developments. In E. L. S.-M. \& V. P. Ritva Kantelinen (Ed.), Seminar Papers on Early Foreign Language Education (pp. 45-55). University of Joensuu.

Putri, D. K., Raharjo, T. J., \& Kustiono. (2020). Area group learning strategies by using Brush Away Technique in identifying fine motor and art skills for kindergarten. Journal of Primary Education, 9(3), 299-306.

Saputri, D. A. (2016). Analysis of teachers' readiness in teaching English to young learners at kindergartens. IAIN Salatiga.

Sayer, P., \& Ban, R. (2014). Young EFL students' engagements with English outside the classroom. ELT Journal, 68(3), 321-329.

Stakanova, E., \& Tolstikhina, E. (2014). Different approaches to teaching English as a foreign language to young learners. Procedia Social and Behavioral Sciences, 456-460.
Sulistiyo, U., Haryanto, E., Widodo, H. P., \& Elyas, T. (2019). The portrait of primary school English in Indonesia: policy recommendations. International Journal of Primary, Elementary, and Early Years Education, 3-13.

Sunyakul, N., \& Teo, A. (2020). Primary school English teachers' application of knowledge/skills from boot camp to their classroom teaching practices and factors hindering their application. LEARN Journal: Language Education and Acquisition Research Network, 13(1), 145-160.

Supriyanti. (2014). Why do our children need to learn English at Primary School? 2nd Conference of Teaching English to Young Learner: From Policy to Classroom.

Supriyanti, N. (2012). Challenges in providing trainings for English teachers of elementary schools. Journal of Education and Learning (EduLearn), 6(3), 161-166.

Turek, A. (2013). Engaging young learners in L2 research (Language Studies Working Papers).

Uysal, N. D., \& Yavuz, F. (2015). Teaching English to very young learners. Procedia Social and Behavioral Sciences, 19-22.

Vroom, S. J., \& Seaman, A. A. (2014). Crosscultural perspectives on teaching English as a foreign language to children: A multinational survey. TESOL Quarterly, 5(3), 465-489.

Wahyudi. (2018). Development of inquirycreative-process learning model to promote critical thinking ability of Physics prospective teachers. IOP Publishing Journal of Physics.

Yussof, N. T., \& Sun, H. (2020). Mismatches between teacher beliefs, practices and reasons for English use in preschool Malay language classrooms. Language and Education, 34(4), 363-382.

Yuwono, G. I., \& Harbon, L. (2010). English teacher professionalism and professional development: Some common issues in 
1387 The Readiness of Teaching English to Young Learners in Indonesia - Syifa Dwi Mutiah, Minkhatun Nakhriyah, Nida Husna HR, Didin Nuruddin Hidayat, Farida Hamid

DOI: https://doi.org/10.31004/basicedu.v4i4.541

Indonesia. Asian EFL Journal, 12(3), 145-

163.

Zein, M. S. (2012). The contexts of English language teaching at primary level in Indonesia. Journal of Teaching and Education, 1(3), 85-90.

Zein, M. S. (2016). Elementary English education in Indonesia: Policy developments, current practices, and future prospects. Professional Development in Education, 42(3), 423-440.

Zein, M. S. (2017). Elementary English education in Indonesia: Policy developments, current practices, and future prospects: How has Indonesia coped with the demand for teaching English in schools? English Today, 33(1), 53-59. 